\title{
The Relevance of Liturgies in the Courts of Classical Athens
}

\author{
By Vasileios Adamidis ${ }^{*}$
}

\begin{abstract}
What was the function of classical Athenian courts? Did they intend to enforce the rule of law? The greatest obstacle to accepting an affirmative answer is the wide use of, at first sight and from a modern (sometimes anachronistic) perspective, remotely relevant argumentation by litigants. In this paper, by reference to Greek ideas of personality, I analyse and demonstrate the legal relevance of extra-legal argumentation in classical Athenian courts, using as a case study the widely criticised invocation of liturgies (public services) by litigants. In particular, by applying a model of human action and ethical motivation which is more appropriate to the Greeks (rather that the unsuitable for the ancient context Cartesian/ Kantian), a better understanding of forensic rhetoric and argumentation is achieved. Therefore, in accordance with Greek psychology, the admittedly liberal approach to legal relevance of the Athenian courts was a calculated step towards the attainment of legal justice and the rule of law as the Athenians perceived it.
\end{abstract}

\section{Introduction}

Extra-legal argumentation was widely used in the courts of classical Athens. ${ }^{1}$ In the ancient forensic speeches litigants proceed to argumentation which seems remotely relevant, if at all, to the legal case. Notwithstanding the fact that ancient sources mention a (legal or quasi-legal) rule of relevance $^{2}$, namely the requirement that litigants ought to speak to the point, litigants resort to arguments which would presumably fail the test of relevance in a modern court. Modern scholars offer differing interpretations of this apparent readiness of the Athenians to accept such material in their courtrooms.

One stream of scholarship attributes great significance to this fact and, as a result, finds the Athenians unwilling to strictly enforce the law in their courts. Since the Athenians permitted quasi-legal evidence to influence their verdicts (as allegedly proved by the continuous presence of such evidence in the speeches) then the implementation of justice based on a strict enforcement of the letter of the law is undermined. Hence, each commentator questions the true role of the courts and substitutes the enforcement of law with alternative propositions. For instance, Cohen argues that the wide use of extra-legal argumentation and the invocation of

* Lecturer/Senior Lecturer, Nottingham Trent University, UK.

1. By the term "extra-legal" I refer to the kind of argumentation that is not directly based on or referring to positive law. By this token, character evidence is considered as a form of extra-legal argumentation, though it clearly has a legal bearing in the sense of supporting the court (and the litigants) as regards the probability of essential facts in order for the legal case to be established.

2. Arist. Rhetoric 1354a22-3; Ath. Pol. 67.1. 
notions such as patriotism and status or the appeals to pity by litigants, support the view that the courts were formulated in such a way as to serve social and political ends. ${ }^{3}$ Todd goes so far as to claim that in Athens, law and politics were ultimately indistinguishable. ${ }^{4}$ Lanni, slightly deviating from this approach, argues that such a wide use of extra-legal argumentation brought about inconsistent verdicts by the Athenian courts, with the result that cases were knowingly judged in an ad hoc basis, the major aim being the attainment of equity. ${ }^{5}$ Osborne mixes up the inherent democratic nature that the Athenians reserved for their system with the purpose that it served and argues that the institutional framework and the courts in particular aimed at the embodiment of the rule of the majority. ${ }^{6}$

The other stream of scholarship, sometimes downplaying the significance of the persistence of marginally relevant argumentation, insists on the attainment of the rule of law by the Athenian courts. Researchers like Ostwald and Sealey, building on the institutional and procedural framework of the Athenian legal system, argue that the Athenians had achieved the strict application of the letter of the law. ${ }^{7}$ Another trend of the same stream approaches this question by the close analysis of the surviving forensic speeches. For instance Harris, Meyer - Laurin, and Meinecke argue for the prominence of the rule of law, embodied in a strictly legal resolution of disputes. ${ }^{8}$ Harris in particular, offering a highly idealised picture of Athenian adjudication, led his critics to observe that he refers to the extralegal argumentation as "stray comments reflecting only the amateurism and informality of the system". ${ }^{9}$ Nevertheless, the continuous and wide presence of character evidence in the delivered speeches makes it too obvious and noteworthy to be considered as simple aberrations to the norm of relevant legal argumentation.

The aim of this paper is to demonstrate the relevance to the legal case of allegedly irrelevant argumentation by particular reference to the invocation

3. D. Cohen, Law, Violence, and Community in Classical Athens (Cambridge: Cambridge University Press, 1995); R. Osborne, "Law in Action in Classical Athens," Journal of Hellenic Studies 105(1985): 40-58; A. Lanni, Law and Justice in the Courts of Classical Athens (Cambridge: Cambridge University Press, 2006).

4. S. C. Todd, The Shape of Athenian Law (Oxford: Clarendon Press, 1993), 29.

5. See A. Lanni, "Relevance in Athenian Courts," Cambridge Companion to Ancient Greek Law (Cambridge: Cambridge University Press, 2005), 112-128; Cf. Lanni, Law and Justice; M.R. Christ, The Litigious Athenian (Baltimore: Johns Hopkins University Press, 1998), esp. 41-2 and 195-6; A. C. Scafuro, The Forensic Stage: Settling Disputes in Graeco-Roman New Comedy (Cambridge: Cambridge University Press, 1997), 50-66.

6. See for e.g. Osborne, "Law in Action in Classical Athens".

7. M. Ostwald, From Popular Sovereignty to the Sovereignty of Law: Law, Society, and Politics in fifth-century Athens (Berkeley: University of California Press, 1986), $497-$ 525; R. Sealey, The Athenian Republic: Democracy or the Rule of Law (University Park and London: Pennsylvania State University Press, 1987), 146-8.

8. H. Meyer - Laurin, Gesetz und Billigkeit im Attischen Prozess [Law and Equity in the Attic Trial], (Weimar, 1965); J. Meinecke, "Gesetzesinterpretation und Gesetzesanwendung im Attischen Zivilprozess" ["Law Interpretation and Application of Law in the Attic Civil Procedure"], Revue Internationale des Droits de l'Antiquite 18(1971): 275-360; E. M. Harris, "Open Texture in Athenian Law," Dike 3 (2000): 27-79.

9. Lanni, "Relevance in Athenian Courts," 113. 
of liturgies by litigants. It will be shown that the deployment of the Greek ideas of personality and human action and their application to the legal setting allow the deduction that extensive reference to extra-legal evidence was received by the court as relevant and served its quest for truth in uncovering the exact facts of the case. Since most disputes in Athenian courts were factual, this liberal approach to the admissibility of evidence, together with the presentation of contextual and background information, facilitated them to uncover the true facts of the case. Afterwards they could proceed to the application of the written law to these facts and, thus, to the attainment of legal justice. The information that the courts received concerning the background and the wider context of a dispute, rather than widening the scope of the legal case in order to induce the jurors to vote in accordance with norms of equity and epieikeia,${ }^{10}$ it actually assisted them to focus more on the innocence or guilt in that particular case and thus to correctly apply the law. ${ }^{11}$ By the same token, litigants' listing of their liturgies as a form of character evidence in support of their legal argumentation acquires probative value.

\section{Human Action and Ethical Motivation}

An analysis of the Greek model of human action and ethical motivation is required before its application to the evidence. Christopher Gill, in his seminal work on Greek "personality", building on the work of modern thinkers, offers a plausible model of interpretation of Greek psychology and motivation. According to him, the preponderate Cartesian model of the human mind, for which mental processes and actions derive from a single source of consciousness (a unitary "I"), can prove misleading when applied to ancient Greek psychology. Contemporary thinkers question the Cartesian model as being overly "subjective", replacing it with a more appropriate, which understands human action in "objective" (non-subject-centred) terms. For instance, human action can be interpreted as motivated by reasons and reasoning, which stem from the agent's past experiences, beliefs, and desires, rather than by conscious acts of will.

Contemporary action-theory accepts that an agent's reasons for a given action provide a plausible causal explanation for that action; this is exactly the suggestion of the Greeks. An agent's reasons for acting can be best understood in objective (third-personal) modes of enquiry. In this light, human action is presented as the result of a process of logical reasoning, whose stages express the human being's beliefs and desires which finally cause that action. This kind of practical syllogism has its roots in the "crucial mark of human rationality", namely the ability to conceptualise (to structure one's responses in terms of universal concepts), and - a capacity

10. On the role of epieikeia see E.M. Harris, The Rule of Law in Action in Democratic Athens (New York: Oxford University Press, 2013), $274 \mathrm{ff}$.

11. Pace Lanni, Law and Justice, $46 \mathrm{ff}$. 
implied by conceptualisation - the ability to reason, to make inferences and draw conclusions.

Inferential reasoning, as a source of human action, can be divided into "means-end" type and "rule-case" type. In both cases the agent decides the "end" to be attained by reference to his beliefs and desires. In the first type of reasoning, the action is directed "through the possible", by evaluating the efficacy and difficulty of available means for achieving that "end". In the second type of reasoning, the present case faced by the agent is placed into a general class. The agent deduces the appropriate mode of action from a preconceived set of actions that form the "rule" which according to his experiences or perceptions can achieve that "end". To use a Homeric example, Odysseus (without considering the available means) applies to his own case the general principle that "whoever is to be best in battle must stand his ground strongly" (Il. 11.409-10). Both types of reasoning, nevertheless, have significant implications for how others perceive, interpret and evaluate a person's actions.

In a similar vein, ancient ethical motivation differs from the modern Kantian and post-Kantian model. The Kantian model presupposes that moral life is grounded in a distinctive individualistic stance adopted by the moral agent. A key example of this idea "is Kant's thesis that the moral response involves, or implies, an act of autonomy, or self-legislation, by which the individual agent binds himself to universal principles". ${ }^{12}$ This fundamentally "individual-centred" approach prescribes that "only the individual herself (the possessor of a uniquely subjective viewpoint) can determine the validity of the rules that she legislates for herself". ${ }^{13}$ Such a "person" exercises her capacity for autonomy by establishing moral principles for herself, in a process that involves "abstraction from localised interpersonal and communal attachments and from the emotions and desires associated with these". ${ }^{14}$

This kind of moral "autonomy" coupled with the "autonomy of the will" presupposed for every single instance of a person's life, have implications for a legal system and its courts. Legal enactments may be interpreted as utilitarian expressions of "positive law" distinct from the ethics of a community. Law, lacking the moral foundation provided by its concurrence with the ("critical" or "conventional") morality of the community, is received as a useful -though independent- tool for subjecting individuals to the governance of "positive" rules. Any connection with ethics might be questioned and ejected from the legal discourse, rendering obsolete any discussion about the identification of legal with moral norms. The significance of the individual's level of adherence to conventional ethics is devalued and the court is viewed as an (ideally) autonomous realm. Furthermore, the notion of "moral autonomy" presupposes the idea that a person's ethical stance should not be evaluated by reference to communal

12. C. Gill, Personality in Greek Epic, Tragedy, and Philosophy: the Self in Dialogue (Oxford: Clarendon Press, 1996), 7.

13. See Gill, Personality in Greek Epic, 9 with n. 27.

14. See Gill, Personality in Greek Epic, 11. 
norms, rendering issues of "merit" based on "overall personality" meaningless. As a result, in modern courts, the admissibility of evidence from character or extra-legal argumentation is restricted, further narrowing the rules of relevance.

On the other hand, the ancient model of ethical motivation promotes a less "individual-centred" approach. According to this, ethical life should be understood "primarily in terms of the development of dispositions by wholehearted engagement in the value-bearing practices, roles, and modes of relationship of a specific society". ${ }^{15}$ Based on the idea that human beings are functionally adapted to participate in interpersonal and communal relationships, this ethical life is at the most fundamental level shared rather than individuated. For Williams, ${ }^{16}$ ethical knowledge is achieved in a life guided by "thick" (culturally localised) ethical values rather than by "thin" (universalised) ones. For MacIntyre, ethical thinking is influenced by a conception of what is required by the "social role" which each individual inhabits. ${ }^{17}$ Thus, in contrast to the Kantian model, the fullest possible (practical and psychological) engagement of the individual with the localised nexus of roles and relationships in which he finds herself, dictates, forms, and transforms the beliefs which produce the desires and ultimately the reasoning for human action. The kind of reasons and reasoning taken to motivate an agent's actions cannot be analysed adequately without reference to her engagement with this localised nexus. In other words the individual agent's actions are based "on reasons and reasoning informed by the actionguiding beliefs of his community and by his engagement with his social role". ${ }^{18}$

This analysis brings out the essence of the different approaches to ethical motivation as exemplified by the aforementioned opposing theories. The implications that such divergent approaches have in courts are obvious, though it might be useful to specify them. The ancient "participant" model of the self presupposes an -as far as possible total- adherence to the communal ethical norms. Any claim to moral "individualism" and any attachment of the individual to "universal" norms become absurd, with the result that such a moral agent becomes "moral outsider" suffering the dreadful (especially for an ancient) penalty of living in isolation. A human being's ethical stance is compared with communally accepted norms, with actions and ethical motives being evaluated according to these. Total adherence to these norms presupposes their practical effectuation, signifying a "worthy", properly motivated social "participant". Additionally, if ethical beliefs are taken as directing human action, then a person proving their internalisation by reference to her previous conduct, and being motivated by the "correct ethical beliefs", renders herself (almost) incapable of "unethical action". Taking into consideration the ancient legal system's identification

15. Gill, Personality in Greek Epic, 7.

16. B. Williams, Shame and Necessity (Berkeley: University of California Press, 1993).

17. A. MacIntyre, After Virtue: A Study in Moral Theory (London: Duckworth (2nd ed.), 1985), 128.

18. Gill, Personality in Greek Epic, 86 and 175-6. 
of "positive" law with "ethical" norms (the first following and officialising the second), then the aforementioned "ethical person" renders herself normally incapable of "illegal action" as well. The ancient "participant" ethical model which holds that adherence to the community's proper ethical beliefs directs virtuous (according to this community's standards) action, renders "character" a central means of evaluating, understanding, and testing human deeds.

\section{The Relevance of Liturgies in Athenian Courts}

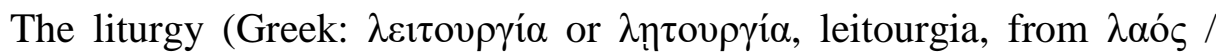
Laos, "the people" and the root है $\rho \gamma o$ / ergon, "work") was a public service established by the official polis whereby its richest members (whether citizens or resident aliens), more or less voluntarily, financed the State with their personal wealth.

The invocation of liturgies in the Athenian courts has been the core of controversy in modern scholarship, perceived as providing the most characteristic type of extra-legal argumentation. On the one hand, scholars insisting on structural interpretations assert that by adducing their liturgies, litigants entered into a contest for honour and prestige. Furthermore, structural tensions of the democratic system such as those between the elite and the demos were regulated and fashioned by the jury's control of Athenian liturgists through the court system (and the final accommodation between rich and poor) or by the elitist implicit threats of withdrawal presented through their orations. ${ }^{19}$ Based on similar methodology, an alternative interpretation is offered by Millett, who sees the liturgies as "disruptive of elite cohesion" and as "a weapon that the rich turned against each other as well as against the egalitarianism of democracy". ${ }^{20}$ Although such interpretations may be valid (as secondary to the main role of the courts as enforcers of the law) they are not free from complications.

The main idea that such invocations were centred on ideas of reciprocity is vulnerable on the following grounds. This notion is better understood in the form of "generalised reciprocity" involving a "gratuitous gesture' on the part of the obligated, thus revealing his noble and unforced generosity rather than a restricted ("quid-pro-quo" type) re-payment of the services. ${ }^{21}$ Furthermore, an (even implicit) assertion that a specific breach of the law could be annulled and redeemed by reference to public services would automatically place the polis (the demos, i.e. the jurors) and its legal

19. See J. Ober, Mass and Elite in Democratic Athens: Rhetoric, Ideology, and the Power of the People (Princeton, N.J.: Princeton University Press, 1989), 226-30 and J.K. Davies, Wealth and the Power of Wealth in Classical Athens (New York: Arno Press, 1981), 88-132 respectively.

20. P. Millett, "The Rhetoric of Reciprocity in Classical Athens," in Reciprocity in ancient Greece, ed. C. Gill, N. Postlethwaite, R. Seaford (Oxford: Oxford University Press, 1998), 250.

21. See W. Donlan, "Reciprocities in Homer," Classical World 75(1981-2): 137-175, 154-71; cf. Gill, Personality in Greek Epic, 133, 139, 142, 145. 
system (which the Athenians highly valued) in a position of inferiority against the assets of a wealthy litigant. ${ }^{22}$ Explicit statements of such type are totally absent from Athenian courts; to impose them on the (implicit) reasoning of the litigants or the (unknown) deliberation of the jurors would be inappropriate. Finally, by adhering to the interpretation of the institution of law (and consequently the courts) as fundamentally designed to break such cycles of reciprocity, I consider it unlikely that Athenian jurors succumbed to such reasoning in defiance of legal justice and their oath. ${ }^{23}$ On the contrary, I would assert that even implicit argumentation of this type would run the great risk of backfiring by alienating the jury, if the latter considered it as irrelevant and obstructive of legal justice.

Even when scholars concentrate on legalistic issues, controversy persists. In this field the main controversy concerns the degree to which the invocation of liturgies by Athenian litigants influenced the verdict of jurors. To offer but a couple of indicative examples, Christ concentrates on the incentives given by wealthy litigants to the jurors to show gratitude (charis) and vote for him by reference to the future material benefit his acquittal will mean for the polis. ${ }^{24}$ Harris convincingly demonstrates by reference to the few known court decisions that such argumentation did not have the force to make the jurors betray their oath and vote contrary to the law. ${ }^{25}$ Harris then goes as far as asserting that the invocation of liturgies aimed at distracting the jurors, though it was relevant at the timesis phase (regarding the assessment of the penalty). ${ }^{26}$ However, such a conclusion is not supported by evidence. ${ }^{27}$ As a matter of fact, since the decisions of Athenian trials rarely survive, any effort to uncover the implicit reasoning of the jurors is based on circumstantial evidence and is largely speculative. In my opinion, applying our model of human action is a valid starting point for a more objective interpretation of the rhetoric of Athenian litigants.

In accordance with our model, the invocation of liturgies may serve to illustrate the character of litigants, by reference to their typical "practical reasoning".

22. The fact that any such statement is absent from the Athenian court speeches is indicative. Gill in Personality in Greek Epic, explains on these terms the rejection of Achilles to the gifts of Agamemnon in Iliad 9. Agamemnon, severely breached the norms of reciprocity between chieftains and an acceptance of the gifts (by the method that Agamemnon chose) would unequivocally place Achilles in a position of inferiority.

23. Cf. R. Seaford, Reciprocity and Ritual: Homer and Tragedy in the Developing City-State (Oxford: Clarendon Press, 1994), Ch. 3 and 6.

24. Christ, Litigious Athenian, 92-3; cf. Lanni, Law and Justice, 46-64.

25. E.M. Harris, "The rule of law in Athenian democracy. Reflections on the judicial oath," Dike 9(2006), 157-81 (= Etica e politica 9 [2007], 55-74), 66-72; cf. Harris, Rule of Law in Action.

26. Harris, "The rule of law in Athenian democracy".

27. See the statistics in S. Johnstone, Disputes and Democracy: the Consequences of Litigation in Ancient Athens (Austin: University of Texas Press, 1999). A close reading of the court orations indicates that the invocation of liturgies was not restricted to timétai dikai. It is hardly convincing to suggest that Athenian litigants, knowing that their liturgies were only relevant during a timesis, would voluntarily and emphatically reveal their implicit purpose of distracting the jurors by asking them to betray their oath. The risk of alienating them would have been extremely high. 
"In regard to the counts of the accusation, you have been sufficiently informed; but I must ask your attention also for what has yet to be added, so that you may understand what kind of person I am before you give your verdict upon me. I was certified of age in the archonship of Theopompus: appointed to produce tragic drama, I spent thirty minae and two months later, at the Thargelia, two thousand drachmae, when I won a victory with a male chorus; and in the archonship of Glaucippus, at the Great Panathenaea, eight hundred drachmae on pyrrhic dancers...I have won a victory with a warship in the race at Sunium, spending fifteen minae; and besides I had the conduct of sacred missions and ceremonial processions and other duties of the sort, for which my expenses have come to more than thirty minae. Of these sums that I have enumerated, had I chosen to limit my public services to the letter of the law, I should have spent not one quarter." (Lys. 21.1, 5)

As a matter of fact, a "rule-case" type of reasoning could lead the jurors to assert whether such a person was capable of performing an illegal deed, ${ }^{28}$ assist the litigant to win their good will and increase the credibility of his character. Frequent, lavish and voluntary liturgies which support the democratic institutions and exceed the requirements of the law reveal by conceptualisation the character of a law-abiding, magnanimous ${ }^{29}$ public benefactor, thus rendering him an unlikely candidate for resorting to antisocial behaviour or for performing a crime. ${ }^{30}$

"I list my liturgies, not for mere vainglory, but to bring in as evidence the fact that the same man cannot both spend a great deal without compulsion and covet some of the public property at the gravest risk." (Lys. 19.56) $^{31}$

Such argumentation is frequently used by defendants and (given the Greek model of human action) not surprisingly, is not rejected by the prosecutors as irrelevant. On the contrary, acknowledging its value, they attempt to diminish the effect of their opponent's public expenditure stating either that this took place out of selfish opportunistic calculation (thus it does not reveal the genuine character of a pro-democratic wealthy philopolis) or that the type of liturgies performed by the opponent was useless to the polis as a whole. ${ }^{32}$

28. Cf. Is. 4.29-30.

29. E.g. Lys. 21.5; Cf. Arist. Rhet. $1366 \mathrm{~b}$ on magnificence and magnanimity as components of virtue.

30. See for e.g. Antiph. 2.2.12; Lys. 7.25, 31, 41; cf..

31. Cf. Dem. 52.26

32. Cf. Lyc. 1.139-40. Lycurgus in particular highlights the ethics of his troubled era by stating that the only useful liturgies at that time were the ones concerned with the war preparation of Athens against its enemies. cf. Lys. 31.12; Dem. 38.25; 42.3, 25. 
"His contributions to the Treasury and his provision of choruses may be satisfactory evidence of his wealth; but they are anything but evidence of his innocence". (Antiph. 2.3.8)

"I do not see how the mass of Athenians are benefited by all the wealth that Meidias retains for private luxury and superfluous display... You ought not to show respect and admiration for such things on every occasion, nor judge a man's public spirit by such tests as thesewhether he builds himself a splendid house or keeps many maidservants or handsome furniture, but whether his splendour and public spirit are displayed in those things in which the majority of you can share."(Dem. 21.159)

The second type of reasoning that has been discussed ("means-end" type) may assist in interpreting more problematic passages, which at first glance appear only remotely relevant to the legal case. The most characteristic and notorious passage is found in Lys. 25.13 which reads:

"But my purpose in spending more than was enjoined upon me by the city was to raise myself the higher in your opinion, so that if any misfortune should chance to befall me I might defend myself on better terms".

Reading merely this statement may leave the impression that a person's liturgies enter into the courtroom as external and irrelevant aid in order to distract the jurors from the facts of the case. However, this case involves a charge of "subverting the democracy". The speaker continues:

"Of all this credit I was deprived under the oligarchy; for instead of regarding those who had bestowed some benefit on the people as worthy recipients of their favours, they placed in positions of honour the men who had done you most harm, as though this were a pledge by which they held us bound. You ought all to reflect on those facts and refuse to believe the statements of these men: you should rather judge each person by the record of his actions."

Even if taken at face value, the statement is clearly relevant to the legal charge by referring to his characteristic attitude towards the demos which cost him his disfavour at the time of the oligarchy. However, we may stretch the analysis more. The speaker is accused of oligarchic affiliations. The period is uneasy since shortly after the fall of the Thirty and the restoration of the democracy such cases were frequent. By reference to "rule-case" type of reasoning, wealthy members of the elite (especially those who stayed in Athens during the reign of the Thirty) were the usual suspects, but also vulnerable targets, of sycophants (Lys. 25.1, 3). The speaker continuously revokes this unjust "rule-case" reasoning which renders him suspect for being disloyal to the democracy. 
"But in fact the sycophants conceive that your resentment against those men [the Thirty] is sufficient to involve in their ruin those who have done no harm at all. [6] I, however, hold that, just as it would be unfair, when some men have been the source of many benefits to the city, to let others carry off the reward of your honours or your thanks, so it is unreasonable, when some have continually done you harm, that their acts should bring reproach and slander upon those who have done no wrong." (Lys.25.5-6)

Switching to a "means-end" type of reasoning, he annuls any ulterior "end" that could be imposed on him by his enemies for his extravagant spending and his great resources. ${ }^{33}$ In this model, the "means" is his lavish expenditure, while the "end" imposed by his opponents could be the showing off of his power which could -stereotypically- render him suspect of subverting the democracy. On the contrary, rejecting this selfish "end", he advertises a different one as the motive for his lavish expenditure. This "end" is pro-democratic (in opposition to the charge with which he is accused), humble and respectful to the power of the demos. This is obvious in the words of the speaker in Lysias 25.13 which have been criticised so much as irrelevant by modern commentators.

The allegation is simple and squares with our model of interpretation: I performed lavish liturgies for the sake of my polis and the democracy because I am a loyal citizen. Knowing that many sycophants lurk, I considered this "means" (performing liturgies) as the best available for proving my character and my loyalty to the constitution. Moreover, he implies, I showed magnanimity in the performance of my liturgies for achieving the "end" of gaining your good will for the sake of justice and out of my respect for and submission to the democratic law court.

Apart from its probative value as regards the agent's practical reasoning, such argumentation may also be indicative of the agent's ethical motivation. Voluntary lavish expenditure for the benefit of the community shows in practice a whole-hearted adherence to the norms of the community. Subsidising the democratic institutions, as well as profusely financing the military of the polis proves the internalisation and adoption of this community's practices and norms. In addition, according to the agent's adherence to his role in the community, lavish performance of public services could be interpreted as "this is how a virtuous member of the elite should act".

The agent's role in the community may be adduced to illuminate cases of naturalised citizens as well:

33. Imposition of a selfish "end by the opponents is not unusual in relation to public services, therefore it is anticipated"; Cf. Lys. 26.4: "As regards the public services, I say that his father would have done better not to perform them than to spend so much of his substance: for it was on account of this that he won the confidence of the people and overthrew the democracy; and so our memory of these deeds must be more abiding than of the offerings he has set up1 in record of those services." 
"Whatever concerns the state, however, and all that concerns you, I perform, as you know, as lavishly as I can; for I am well aware that for you who are citizens by birth it is sufficient to perform public services as the laws require; we on the contrary who are created citizens ought to show that we perform them as a grateful payment of a debt. " (Dem. $45.78,85)$

A citizen's role dictated the subordination of his oikos' obligations to the ones of the polis:

" [...] never once when I had to perform a public service in your aid did I consider it a hardship that I should leave my children so much the poorer, but much rather that I should fail in the zealous discharge of my obligations. " (Lys. 21.23)

The frequent invocation of liturgies is best understood as the culmination of the ancient model of practical reasoning and ethical motivation. In this light they become surprisingly relevant in forensic settings.

\section{Bibliography}

Christ, M.R. The Litigious Athenian. Baltimore: Johns Hopkins University Press, 1998.

Cohen, D. Law, Violence, and Community in Classical Athens. Cambridge: Cambridge University Press, 1995.

Davies, J.K. Wealth and the Power of Wealth in Classical Athens. New York: Arno Press, 1981.

Donlan, W. "Reciprocities in Homer." Classical World 75(1981-2): 137-175.

Gill, C. Personality in Greek Epic, Tragedy, and Philosophy: the self in dialogue. Oxford: Clarendon Press, 1996.

Harris, E. M. "Open Texture in Athenian Law." Dike 3(2000): 27-79.

Harris, E. M. "The rule of law in Athenian democracy. Reflections on the judicial oath." Dike 9 (2006), 157-81 (= Etica e politica 9 [2007], 55-74).

Harris, E. M. The Rule of Law in Action in Democratic Athens. New York: Oxford University Press, 2013.

Johnstone, S. Disputes and Democracy: the Consequences of Litigation in Ancient Athens. Austin: University of Texas Press, 1999.

Lanni, A. "Relevance in Athenian Courts." Cambridge Companion to Ancient Greek Law, 112-128. Cambridge: Cambridge University Press, 2005.

Lanni, A. Law and Justice in the Courts of Classical Athens, Cambridge: Cambridge University Press, 2006.

MacIntyre, A. After Virtue: A Study in Moral Theory. London: Duckworth (2 $^{\text {nd }}$ ed.), 1985.

Meinecke, J. "Gesetzesinterpretation und Gesetzesanwendung im Attischen Zivilprozess" ["Law Interpretation and Application of Law in the Attic Civil Procedure"]. Revue Internationale des Droits de l'Antiquite (1971) 18: 275-360.

Meyer - Laurin, H. Gesetz und Billigkeit im Attischen Prozess [Law and Equity in the Attic Trial]. Weimar, 1965. 
Millett, P. "The Rhetoric of Reciprocity in Classical Athens." In Reciprocity in Ancient Greece, edited by C. Gill, N. Postlethwaite, R. Seaford. Oxford: Oxford University Press, 1998.

Ober, J. Mass and Elite in Democratic Athens: Rhetoric, Ideology, and the Power of the People. Princeton, N.J.: Princeton University Press, 1989.

Osborne, R. "Law in Action in Classical Athens." Journal of Hellenic Studies 105(1985): 40-58.

Ostwald, M. From Popular Sovereignty to the Sovereignty of Law: Law, society, and Politics in fifth-century Athens. Berkeley: University of California Press, 1986.

Scafuro, A. C. The Forensic Stage: Settling Disputes in Graeco-Roman New Comedy. Cambridge: Cambridge University Press, 1997.

Seaford, R. Reciprocity and Ritual: Homer and Tragedy in the Developing CityState. Oxford: Clarendon Press, 1994.

Sealey, R. The Athenian Republic: Democracy or the Rule of Law. University Park and London: Pennsylvania State University Press, 1987.

Todd, S. C. The Shape of Athenian Law. Oxford: Clarendon Press, 1993.

Williams, B. Shame and Necessity. Berkeley: University of California Press, 1993. 